\title{
Pembentukan Peraturan Daerah Syari'ah dalam Perspektif Hukum Tata Negara Pascareformasi
}

\author{
Erfina Fuadatul Khilmi \\ IAIN Jember, Indonesia \\ erfinakhilmi@gmail.com
}

\begin{abstract}
Indonesia in the aftermath of Reformation, the relationship between powers of central and local governments has shifted the paradigm in which the power of central government from centralizedauthoritarian to decentralized-autonomy. One of decentralized powers of local government is by providing the power to self-regulate without any intervention from central government, including the initiative to establish bylaws (Peraturan Daerah) as the results of local autonomy. In further development of authonomy, however, the wider decentralization and autonomy attached to local governments has been responded differently. One of such responses is the establishment of sharia bylaws in which they result in problems in the Indonesian constitutional law system. From constitutional perspective, bylaws in local governments other than Aceh province violate citizen's constitutional rights by which those are not accomodated in the hierarcy of national regulations. On the other hand, however, the establishment of sharia bylaw is important as a means to nurture social morality. Accordingly, there should not be abandonment regarding the establishment of sharia bylaws in several local governments other than Aceh province. But, the reaffirmation is needed relating to the position of sharia bylaws in the constitutional perspective which is not only seen formally, but also materially.
\end{abstract}

KEYWORDS: Post-Reformation, Decentralistizatiom, Shari'a Bylaws, Constitutional Law.

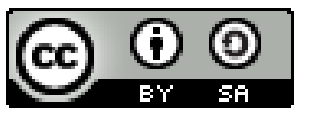

Copyright $\odot 2018$ by Author(s) International License. All writings published in this journal are personal views of the authors and do not represent the views of this journal and the author's affiliated institutions.

\section{HOW TO CITE:}

Khilmu, Erfina Fuadatul. "Pembentukan Peraturan Daerah Syari'ah dalam Perspektif Hukum Tata Negara Pascareformasi" (2018) 5:1 Lentera Hukum 47-62.

Submitted: March 19, 2018 Revised: March 29, 2018 Accepted: April 27, 2018 


\section{PENDAHULUAN}

Sejak reformasi digulirkan pada tahun 1998, secara subtansial dan signifikan terjadi perubahan tatanan kehidupan di bidang politik pascaperubahan Undang-undang Dasar Negara Republik Indonesia Tahun 1945 (UUD 1945). Salah satu perubahannya adalah mengenai hubungan kekuasaan antara pemerintah pusat dan daerah yang mengalami pergeseran kewenangan pemerintah pusat dari sentralistik-otoritarian menjadi kewenangan desentralistik otonom. Hal tersebut nampak pada pasal 18 ayat (2) yang lebih menempatkan keleluasaan pemerintah lokal/daerah untuk mengelola urusan rumah tangganya sendiri setelah pemerintah pusat melimpahkan kewenangannya kepada daerah.

Kehendak politik dari UUD 1945 Perubahan, sangat berbeda dengan kebijakan semasa orde baru yang lebih menekankan pada aspek stabilitas, integrasi dan pengendalian secara sentralistik melalui perencanaan terpusat, sehingga menimbulkan kebijakan penyeragaman dan patronase politik yang mematikan kreativitas daerah. ${ }^{1}$ Sedangkan dalam desentralisasi ketatanegaraan atau sering disebut desentralisasi politik, telah diberikan kewenangan kepada daerah, yang salah satunya adalah membentuk dan menyusun peraturan daerah dengan tetap memperhatikan ciri khas dan karakter masing-masing daerah. ${ }^{2}$ Penyelenggaraan desentralisasi dan otonomi seluas-luasnya diatur lebih lanjut melalui pemberlakuan Undang-undang Nomor 23 Tahun 2014 tentang Pemerintahan Daerah dan selanjutnya disebut dengan Undangundang Pemerintahan Daerah. Hal inilah yang kemudian menjadi arah politik hukum dalam hubungan kekuasaan pusat dan daerah pasca Reformasi yang meskipun kedaulatan aslinya berada pada pemerintah nasional atau pusat, tetapi peluang adanya ketidakseragaman kebijakan antara pusat dan daerah merupakan suatu keniscayaan dalam pemberian otonomi seluas-luasnya kepada daerah dengan tetap memperhatikan kondisi, kekhasan, dan kearifan lokal yang ditentukan secara tegas sebagaimana diatur dalam undang-undang. ${ }^{3}$ Hal tersebut ditujukan dalam rangka untuk lebih meningkatkan kualitas keadilan, demokrasi dan kesejahteraan bagi segenap bangsa Indonesia yang plural dan beragam di Negara Kesatuan Republik Indonesia (NKRI).

Konsekuensi adanya desentralisasi politik melalui otonomi luas ternyata direspon sangat beragam dan berbeda antara satu daerah dan daerah lainnya, sehingga mendorong Pemerintah Daerah melakukan improvisasi, kreasi, inovasi dan berlomba-

\footnotetext{
Moh. Mahfud MD, Membangun Politik Hukum Menegakkan Konstitusi, (Jakarta: PT.Rajagrafindo Persada, 2010), hlm 222.

2 Kewenangan Pemerintahan daerah dalam merumuskan dan menyusun Perda pasca reformasi lebih berorientasi kepada kepentingan masyarakat sendiri dan aspirasi rakyat setempat sesuai dengan kondisi, potensi, karakteristik yang dimilikinya. Hal tersebut menjadi faktor yang strategis dan penting dalam proses pembentukan perda karena akan menjadi lebih responsif kepada tuntutan warganya, dan akan lebih efektif dalam pemberlakuannya dengan didukung oleh sistem dan mekanisme akuntabilitas, transparan, terbuka dan pelibatan masyarakat secara aktif. Tentunya, pelaksanaan otonomi nyata atau otonomi riil yang demikian ini lebih sulit dibandingkan dengan yang serba seragam. Lihat selengkapnya dalam Bagir Manan, Menyongsong Fajar Otonomi Daerah, (Yogyakarta: Pusat Studi Hukum (PSH) Fakultas Hukum UII, 2002), hlm. 13.

3 Jimly Asshiddiqie, Pokok-pokok Hukum Tata Negara Indonesia, (Jakarta: PT. Bhuana Ilmu Populer, 2007), hlm. 290-291.
} 
lomba untuk merumuskan berbagai peraturan daerah (Perda) yang sesuai dengan keunikan daerah masing-masing, termasuk keunikan keberagamaannya. Semangat otonomi yang berlebihan ini memberi peluang terhadap beberapa daerah yang mengklaim memiliki basis Islam kuat untuk menerbitkan Perda bermuatan agama atau lebih dikenal dengan Perda Syariah. ${ }^{4}$ Tetapi, Perda Syariah tersebut menjadi perdebatan dan polemik karena daerah-daerah yang menerapkan Perda Syariah ini bukanlah daerah yang diberikan otonomi khusus oleh Pemerintah Pusat, sebagaimana Nanggroe Aceh Darussalam (NAD) melalui Undang-undang Nomor 44 Tahun 1999 tentang Keistimewaan Daerah Aceh yang diperkuat dengan Undang-undang No. 11 Tahun 2006 tentang Pemerintahan Aceh.

Menurut ketentuan Undang-undang Pemerintahan Daerah, menegaskan bahwa pemerintah pusat memiliki kewenanganabsolut yang tidak dapat dibagi oleh Pemerintah daerah, salah satunya adalah urusan agama. ${ }^{5}$ Meski demikian, Pemerintah sendiri melalui Kementerian Dalam Negeri tidak melakukan pembatalan terhadap adanya perda syariah ini. Rata-rata perda yang dibatalkan oleh Menteri Dalam Negeri adalah perda yang berhubungan dengan pendapatan daerah seperti, perizinan, investasi, atau retribusi yang tidak perlu. ${ }^{6}$ Tetapi, tindakan Pemerintah Pusat yang tidak tegas terhadap kebijakan produk daerah bernuansa syariah menunjukkan inkonsistensi dalam menerapkan hubungan desentralisasi antara pemerintah pusat dengan daerah sebagaimana yang telah diatur dalam undang-undang Pemerintahan Daerah.

Berpangkal uraian diatas, maka pembentukan Perda Syariah menjadi fenomenal dalam sistem hukum ketatanegaraan Indonesia. Hal ini dikarenakan ada indikasi ketimpangan dalam memahami antara nilai-nilai dan norma hukum yang direfleksikan melalui kehendak politik konstitusi mengenai Indonesia sebagai negara kesatuan yang berdasarkan atas prinsip hukum. Hal tersebut, tentunya akan mempengaruhi materi muatan Perda dan tidak boleh ada pembiaran mengenai pembentukan Perda Syariah di

4 Perda syariah dalam tulisan ini dimaknai sebagai peraturan daerah yang materinya diambil dari ketentuan-ketentuan legal syariat Islam, baik yang bersifat tekstual maupun substansi ajarannya. Dalam dinamika perkembangannya, Perda Syariah dapat dikategorikan ke dalam 4 kategori, yaitu: (a) Perda yang terkait isu moralitas, yang juga diatur oleh agama lainnya, seperti Perda tentang larangan berjudi, prostitusi, dan mengkonsumsi minuman alkohol; (b) Perda yang terkait fashion dan mode pakaian, seperti keharusan memakai jilbab dan baju muslimah; (c) Perda terkait keterampilan beragama, seperti keharusan pandai baca tulis Al-quran; (d) Perda yang menyangkut persoalan dana social dari masyarakat, seperti pengelolaan zakat, infaq,dan sadaqah Lihat selengkapnya dalam Warijo, Politik Belah Bambu Jokowi: Dari Mafia Politik Sampai Islamfobia, (Medan:Puspantara,2015), hlm. 13-14.

5 Pasal 10 ayat (1) Undang-Undang Pemerintahan Daerah, menegaskan bahwa urusan pemerintahan absolut yang menjadi kewenangan Pemerintah Pusat, meliputi: a. politik luar negeri; b. pertahanan; c. keamanan; d. yustisi; e. moneter dan fiskal nasional; dan f. agama.

6 Kementerian Dalam Negeri membatalkan 3.143 Peraturan Daerah (perda) yang dinilai bermasalah. Menteri Dalam Negeri Tjahjo Kumolo menegaskan dari 3.143 itu, tidak ada perda syariat Islam yang termasuk dibatalkan. Rata-rata yang dibatalkan adalah perda-perda itu dinilai menyulitkan proses perizinan sehingga memperlambat laju perekonomian daerah seperti, urusan ekonomi, investasi dan perizinan. Sedangkan, Perda syariah tidak dibatalkan. Lihat dalam Roy Jordan, Mendagri: Tidak Ada Penghapusan Perda Syariat Islam https:/news.detik.com/berita/3234905/mendagri-tidak-adapenghapusan-perda-syariat-Islam, diakses Kamis 16 Juni 2016, Pukul 13.57 WIB. 
beberapa daerah selain Aceh. Oleh karena itu, dalam tulisan ini akan memaparkan dan menegaskan kembali terkait kedudukan Perda Syariah dalam perspektif hukum tata negara yang tidak hanya dilihat dari aspek formil saja tetapi konsep hukum tata negara dalam arti luas (materiil).

\section{KEDUDUKAN PERDA SYARIAH BERDASARKAN HUKUM TATA NEGARA DALAM ARTI FORMIL}

Perda Syari'ah adalah suatu peraturan yang bermuatan nilai dan atau norma Islam yang bersumber dari Al-qur'an dan Sunnah yang berlaku disuatu daerah. Dalam kajian hukum Islam istilah syariah dibedakan antara syari'ah arti sempit dan syari'ah arti luas. Syari'ah dalam arti sempit berarti teks-teks wahyu atau hadis yang menyangkut masalah hukum normatif. Sedang dalam arti luas adalah teks-teks wahyu atau hadis yang menyangkut aqidah (keyakinan) hukum dan akhlak. ${ }^{7}$ Perda Syari'ah yang digunakan dalam tulisan ini adalah syari'ah dalam arti sempit, yaitu teks wahyu atau hadis yang tidak ada intervensi manusia. Hal ini berarti bersifat sempit ritual yang mencakup juga perjudian, maksiat, pelacuran, larangan wanita keluar malam dan sebagainya.

Keberadaan Perda Syariah apabila ditinjau dari segi hukum tata negara dalam arti formil, berarti hanya menyangkut peraturan perundang-undangan yang tertulis. Secara normatif, kewenangan otonom Pemerintahan Daerah dalam merumuskan Peraturan Daerah itu harus berdasarkan keunikan dan ciri khas masing-masing daerah, sebagaimana dinyatakan dalam Pasal 14 Undang-undang Nomor 12 Tahun 2011 tentang Pembentukan Peraturan Perundang-undangan, yang menyatakan bahwa Materi muatan Peraturan Daerah Provinsi dan Peraturan Daerah Kabupaten/Kota berisi materi muatan dalam rangka penyelenggaraan otonomi daerah dan tugas pembantuan serta menampung kondisi khusus daerah dan/atau penjabaran lebih lanjut Peraturan Perundang-undangan yang lebih tinggi.

Prinsip kekhususan daerah menjadi faktor penting dalam penyusunan Perda karena otonomi yang riil atau nyata itu ditentukan oleh berbagai keadaan khusus oleh masing-masing daerah untuk mewujudkan cita-cita otonomi masyarakat daerah yang demokratis dan sejahtera. ${ }^{8}$ Namun, dalam tataran implementatif, Peraturan Daerah diasumsikan sebagai produk politik yang didominasi oleh kekuatan politik terbesar melalui kehendak para pemimpin daerahnya yang merupakan representasi keinginan rakyat, sehingga setiap daerah seakan merasa perlu dan memiliki kewenangan tanpa batas dalam menerapkan beragam regulasi yang diinginkan, termasuk menerapkan syari'at Islam di daerahnya karena dianggap dapat mengembalikan identitas masyarakat daerah yang religius seperti masa lalu. Hal ini merupakan konsekuensi logis adanya otonomi daerah yang menjadi wewenang kepala daerah dalam membahas,

\footnotetext{
Muntoha, Otonomi Daerah dan Perkembangan Peraturan Daerah Bernuansa Syariah, (Yogyakarta: Safiria Insania Press, 2010), hlm. 15.

8 Bagir Manan, supra note $2 \mathrm{hlm} .13$.
} 
merumuskan dan menetapkan Perda setelah mendapat persetujuan DPRD sebagaimana diatur secara tegas dalam UU Pemerintahan Daerah. ${ }^{9}$

Perda syariah yang sama pembentukannya dengan perda biasa telah berimplikasi terhadap tuntutan di beberapa daerah di Indonesia untuk ditegakkannya syariat Islam berdasar atas kewenangan Pemerintahan Daerah dan faktor kekhususan yang dimiliki daerah tersebut, misalnya pada Provinsi Aceh. Melalui Undang-undang No.44/1999 tentang Keistimewaan Daerah Istimewa Aceh., maka daerah provinsi Aceh diberi kewenangan khusus untuk mengatur dan mengurus sendiri urusan pemerintahan dan kepentingan masyarakat setempat. Kemudian diikuti dengan pembentukan UU No.18/2001 tentang otonomi khusus bagi provinsi daerah Aceh yang kemudian dicabut dengan UU No. 11 Tahun 2006 tentang Pemerintahan Aceh. Berdasarkan peraturan perundang-undangan tersebut, bahwa syari'at Islam diizinkan dan diakui keberadaannya dalam hukum nasional. Meski perlu dicatat untuk pelaksanaan syariat Islam tingkat undang-undang secara ekpilisit baru dinyatakan secara tegas berlaku di Aceh dan tidak belum berlaku didaerah lain. Itu artinya secara eksplisit, syariat Islam yang berdasarkan level hukum undang-undang baru eksis dan berlaku secara terbatas di Aceh. Sehingga, dari sisi teori hukum berlaku asas hukum, lex spesialis yaitu aturan hukum khusus yang mengecualikan aceh dari Undang-undang Pemerintahan Daerah.

Pengadopsian syariat Islam ke dalam Peraturan Daerah di beberapa daerah. Bersamaan dengan diberikannya hak otonomi khusus Aceh dan UU Pemerintahan Daerah maka pengadopsian bentuk Perda semakin marak dan menjamur setelah proses reformasi 1999. Pemberlakuan Perda yang mengandung muatan syariah Islam adalah berkaitan dengan urusan agama yang seharusnya termasuk kewenangan absolut Pemerintah Pusat dan tidak dapat dibagi oleh pemerintah daerah, sebagaimana dinyatakan dalam Pasal 10 ayat 1 UU Pemerintahan Daerah yang menyatakan bahwa urusan pemerintahan absolut meliputi: politik luar negeri, pertahanan keamanan, peradilan, moneter dan fisikal nasional serta agama. Selain itu, di ayat (2) juga menegaskan bahwa urusan pemerintahan absolut dapat dilaksanakan sendiri oleh Pemerintah Pusat dan melalui asas dekonsentrasi. Hal ini berarti urusan agama ditempatkan sebagai urusan absolut Pemerintah Pusat yang tidak dapat dibagi dengan daerah kabupaten dan semestinya daerah-daerah itu tunduk terhadap undang-undang Pemerintahan Daerah.

Selain itu, pembentukan peraturan daerah tersebut tentunya harus menjamin dan menghormati nilai-nilai HAM. Hal ini berarti dalam prosesnya terdapat penyusunan yang taat prosedural sesuai kewenangan dan ketentuan yang disepakati, serta memberikan kesempatan secara adil kepada setiap anggota masyarakat secara

\footnotetext{
Berdasarkan Pasal 65 ayat (2) UU No. 23/2014 Dalam melaksanakan tugas sebagaimana dimaksud pada ayat (1) kepala daerah berwenang:

a. mengajukan rancangan Perda;

b. menetapkan Perda yang telah mendapat persetujuan bersama DPRD;

c. menetapkan Perkada dan keputusan kepala daerah;

d. mengambil tindakan tertentu dalam keadaan mendesak yang sangat dibutuhkan oleh Daerah dan/atau masyarakat; dan

e. melaksanakan wewenang lain sesuai dengan ketentuan peraturan perundang-undangan
} 
transparan dan partisipatif. ${ }^{10}$ Apabila pembentukan Perda syariah sama dengan perda biasa, maka perlu dipertanyakan lagi terkait adanya prinsip keterbukaan dalam proses perencanaan, penyusunan, dan pembahasan pembentukan Perda. Pelibatan masyarakat yang tanpa diskriminasi dan berpartisipasi dalam perumusan pembentukan peraturan serta isu-isu kelompok rentan dan minoritas harus menjadi prioritas utama dalam pembuatan perda. Namun, dalam tataran implementatifnya, pembentukan perda syariah melahirkan perdebatan dan fenomenal ketika dalam proses penyusunannya tidak melibatkan masyarakat, seperti misalnya Perda No.8 Tahun 2005 tentang Pelarangan Pelacuran.

Keberpihakan perda itu terhadap perempuan tidak berimbang, sehingga terdapat indikasi tidak melibatkan perempuan dalam pembentukan aturan itu. Di salah satu pasalnya yaitu Pasal 4 ayat (1) yakni, setiap orang yang bersikap atau perilakunya mencurigakan, sehingga menimbulkan suatu anggapan bahwa ia/mereka pelacur dilarang berada di jalan-jalan umum, di lapangan-lapangan, di rumah penginapan, losmen, hotel, asrama, rumah penduduk/kontrakan, warung-warung kopi, tempat liburan, gedung tempat tontonan, di sudut-sudut jalan atau di lorong-lorong atau tempat-tempat lain di daerah. Rumusan ketentuan kata "mencurigakan" menjadi salah satu klausula yang mengandung multitafsir dan mengarah kepada ketidakpastian hukum karena tidak memenuhi unsur objektif dalam suatu kaidah pelarangan dan kecurigaan itu lebih mengarah kepada pihak perempuan.

Apabila dikaitkan dengan hierarki norma dalam Pasal 7 ayat (1) Undang-undang No.12/201l tentang pembentukan peraturan perundang-undangan maka jelas nyatalah bahwa Perda yang bermuatan syariah yang kedudukannya berada di bawah undangundang dan jenisnya adalah produk hukum yang dibuat oleh legislasi dan pemerintah di tingkat lokal. Sehingga, dapat dikatakan cacat yuridis karena dalam berlaku asas hukum lex superior derogate legi inferior. Artinya peraturan yang lebih tinggi akan mengesampingkan peraturan yang lebih rendah apabila mengatur substansi yang sama dan bertentangan.

Selain itu, Perda Syariah apabila ditinjau dari substansi materi muatan Peraturan Perundang-undangan sangat rentan menimbulkan diskriminasi bagi sebagian kelompok masyarakat, misalnya penulis ambil contoh pembentukan Perda Kota Malang No 8 Tahun 2005 tentang Larangan Tempat Pelacuran dan Perbuatan Cabul. Ada beberapa hal yang harus diperhatikan terkait substansi materi muatan Perda menurut Undang-Undang Nomor 12 Tahun 2011 tentang Pembentukan Peraturan Perundang-undangan, antara lain asas pengayoman, kemanusiaan, kekeluargaan keadilan dan kesamaan.

Asas pengayoman merupakan asas di mana materi muatan perundang-undangan berfungsi memberikan perlindungan terhadap kelompok yang marginal dan minoritas. Dengan dibentuknya Perda ini, sebagian kelompok masyarakat khususnya perempuan yang memiliki aktivitas dan bekerja, khususnya di malam hari mengalami diskriminasi

10 Nukila Evanty, dkk, Paham Peraturan Daerah (Perda) Berperspektif HAM (hak asasi manusia), (Jakarta: PT. Raja Grafindo Persada, Cet I, 2014), hlm. 93. 
Karena ada beberapa pasal yang menegaskan tentang larangan berjalan mondar mandir ditempat penginanpan dan berjalan di tempat umum pada malam hari. Sedangkan asas kemanusiaan menegaskan bahwa materi muatan peraturan perundang-undangan harus mencerminkan pelindungan dan penghormatan hak asasi manusia. Namun, penerapan perda ini berpotensi menuduh perempuan atas dasar kecurigaan bukan atas dasar hukum yang jelas.

Asas kekeluargaan merupakan asas di mana materi muatan peraturan perundangundangan harus mencerminkan musyawarah untuk mencapai mufakat dalam setiap pengambilan keputusan. Setiap Perda yang dibuat oleh Pemerintah Daerah harus melibatkan partisipasi masyarakat, khususnya kelompok perempuan yang perlu dilibatkan dalam pembentukan perda sehingga materi/substansi perda lebih berkeadilan gender. Sedangkan asas keadilan adalah bahwa setiap Materi Muatan Peraturan Perundang-undangan harus mencerminkan keadilan secara proporsional bagi setiap warga negara. Prinsip keadilan dalam perda ini lebih menekankan apada aspek moralitas agama tertentu yang diformalkan, sehingga materi muatannya lebih banyak menyudutkan perempuan sebagai objek yang sangat buruk dalam Perda ini. Implikasinya, perda ini juga membatasi hak-hak perempuan untuk mendapatkan penghidupan layak yang dijamin dalam konstitusi. Selanjutnya, asas kesamaan berarti kedudukan dalam hukum dan pemerintahan adalah bahwa setiap Materi Muatan peraturan perundang-undangan tidak boleh memuat hal yang bersifat membedakan berdasarkan latar belakang, antara lain, agama, suku, ras, golongan, gender, atau status sosial. Oleh karena itu, prinsip kesetaraan harus dijamin dan dilindungi dalam Peraturan Daerah sebagai bagian dari peraturan perundang-undangan.

\section{KEDUDUKAN PERDA SYARIAH BERDASARKAN HUKUM TATA NEGARA DALAM ARTI MATERIIL}

Sebagaimana dikemukakan oleh Jimly Asshiddiqie, yang menyatakan bahwa hukum tata negara haruslah diartikan sebagai hukum dan kenyataan praktik yang mengatur tentang nilai-nilai luhur dan cita-cita kolektif rakyat suatu negara, format kelembagaan organisasi negara, mekanisme hubungan antar lembaga negara, dan mekanisme hubungan antar lembaga negara dengan warga negara. ${ }^{11}$ Hal ini berarti bahwa pembentukan perda syariah berdasarkan hukum tata negara dalam arti luas merupakan satu kesatuan yang kompleks terhadap unsur-unsur yuridis dengan tetap berdasarkan pada prinsip negara kesatuan melalui sistem desentralisasi yang proporsional.

\section{A. Perspektif Konstitusi dalam Arti Materiil}

Perspektif konstitusi dalam arti materiil, yakni terkait dengan konsensus kolektif mengenai prinsip-prinsip hubungan agama dengan negara dan jaminan perlindungan hak asasi manusia. Hubungan negara dengan agama seringkali menjadi persoalan

"l Jimly Asshiddiqie, Pengantar Ilmu Hukum Tata Negara, Cet.6 (Jakarta: Raja Grafindo Persada, 2014), hlm. 29. 
krusial dan sensitif di Indonesia. Persoalan tersebut mengakibatkan perselisihan dan perdebatan yang tidak kunjung selesai. Secara historis, perdebatan antara kelompok Islam yang mengupayakan konstitusionalisasi Islam dengan kelompok kebangsaan pada mulanya terjadi pada saat proses sidang BPUPKI tahun 1945. Usaha kompromi antara golongan Islam dengan golongan kebangsaan menghasilkan piagam Jakarta yang terkenal dengan tujuh kata, "dengan kewajiban menjalankan syariat Islam bagi pemeluknya". Namun, atas prakarsa Mohammad Hatta, setelah orang-oranag Indonesia Timur keberatan atas klausul tujuh kata tersebut, tujuh kata tersebut dihapus dengan pertimbangan untuk menjaga persatuan bangsa. ${ }^{2}$ Perdebatan ini berlanjut pada tahun 1956-1959 untuk memasukkan kembali piagam Jakarta kedalam konstitusi, namun ini di intervensi oleh Soekarno dengan membuat dekrit 5 Juli 1959. Terakhir, pada proses amandemen UUD 1999-2002 yang ditolak karena tidak mendapat dukungan dari fraksi-fraksi yang ada di MPR ${ }^{13}$ Peluang inilah yang kemudian dimanfaatkan oleh kelompok pengusung Piagam Jakarta setelah mengalami kegagalan dalam memperjuangkan Islam sebagai hukum nasional di tingkat pusat akhirnya beralih untuk mempengaruhi daerah-daerah yang memiliki basis Islam kuat. Melalui otonomi daerah, kelompok tersebut mempengaruhi legislatif-eksekutif daerah untuk menerbitkan Perda yang memiliki materi muatan agama ritual secara sempit atau dikenal dengan Perda Syari'ah. Kecenderungan dari beberapa kelompok Islam yang demikian ini, membuat Perda Syariah menjadi hukum yang riil di daerah yang berbasis Islam.

Dalam rangka menyelesaikan persoalan tarik menarik tentang perlunya formalisasi agama dalam negara, maka kita perlu memahami prinsip-prinsip konstitusi yang didalamnya mengandung muatan Pancasila sebagai nilai-nilai luhur dan cita-cita kolektif rakyat. Prinsip pertama Pancasila, yaitu prinsip Ketuhanan YME menurut dasar kemanusiaan yang adil dan beradab sebagaimana termuat dalam Pembukaan UUD 1945 alinea ke 4. Prinsip tersebut menempatkan Indonesia bukan negara agama dan juga bukan negara sekuler. Artinya, Indonesia tidak mewakili dan tidak didikte oleh agama tertentu tetapi meskipun demikian, nilai-nilai agama dapat dijadikan sebagai nilai etis dalam kehidupan publik, sebagaimana dikemukakan oleh Roeslan Abdoelgani, yakni Negara Indonesia berdasarkan Pancasila, sila Ketuhanan Yang Maha Esa, bukanlah negara yang terpisah dari agama, tetapi juga tidak menyatu dengan agama. Tidak terpisah, karena secara aktif dinamis membimbing, menyokong,

12 Yudi Latif, Negara Paripurna historisitas, rasionalitas, dan aktualitas Pancasila, (Jakarta: PT Gramedia, Cet.5, 2015), hlm. 83.

13 Setelah reformasi bergulir, terdapat upaya untuk memasukkan kembali tujuh kata Piagam Jakarta. Hal ini terbukti di akhir masa sidang tahunan MPR 2002, sejumlah partai politik Islam, seperti PPP dan PBB secara tegas menuntut dimasukannya tujuh kata dalam Piagam Jakarta dalam amandemen pasal 29 ayat 1 UUD 1945. Upaya tersebut mengalami kegagalan karena kurangnya dukungan politik MPR maupun dukungan sosiologis dari masyarakat. Akibat kegagalan pada tingkat nasional untuk menjadikan konstitusi negara berdasar syari'at Islam membuat beberapa kalangan akhirnya beralih ke daerah Lihat selengkapnya dalam jurnal Denny Indrayana, Kompleksitas peraturan daerah bernuansa syari'at prespektif hukum tata negara, (tidak ada kota : Jurnal Yustisia Edisi 81 September-Desember 2010), hlm. 98. 
memelihara dan mengembangkan agama. Tidak menyatu dengan negara, karena negara tidak mewakili dan tidak memberikan keistimewaan kepada salah satu agama. ${ }^{14}$

Berpangkal uraian diatas, maka konsistensi negara untuk memelihara dan menjamin kebebasan beragama adalah melindungi komunitas/kelompok agama untuk menjalankan hukum agamanya masing-masing sebagaimana dijamin secara konstitusional dalam UUD 1945 pada pasal 29 ayat (2) yang menyatakan bahwa negara menjamin kemerdekaan tiap-tiap penduduk untuk beribadat menurut agama dan kepercayaannya itu. Hal ini menunjukkan konotasi positif dari arah politik negara terkait persoalan hubungan negara dan agama. Provinsi Daerah Istimewa Aceh adalah daerah yang bersifat khusus yang penyelenggaraannya harus secara khusus sesuai dengan karakteristik dan kondisi daerah yang bersangkutan. ${ }^{15}$

Karakteristik masyarakat Aceh yang dikatakan khusus disini adalah terkait penerapan hukum Islam dan hukum adat yang telah menyatu dalam pandangan hidup masyarakat aceh, sehingga membentuk identitas yang dipegang masyarakat Aceh dalam setiap semua aspek kehidupan masayarakat Aceh, mulai dari siasat peperangan, kesenian, pergaulan masyarakat, pendidikan dan pengajaran sampai kepada kehidupan sosial-masyarakat lainnya. ${ }^{16}$ Pembentukan identitias syariat Islam yang dimiliki masyarakat Aceh ini dipengaruhi oleh proses sejarah yang panjang semenjak masa awal penyebaran Islam keluar jazirah Arab. ${ }^{17}$ Dengan demikian, dapat dikatakan bahwa Pembentukan Perda Syariah di Daerah Istimewa Provinsi Aceh tidak melanggar prinsip-prinsip konstitusi UUD 1945 Perubahan pasal 18 B ayat (1), yakni pengakuan terterhadap satuan-satuan pemerintahan daerah yang bersifat khusus atau istimewa dan membenarkan suatu komunitas menjalankan hukum agamanya sesuai UUD 1945 pasal 29 ayat (2).

Berbeda dengan pembentukan Perda Syariah di beberapa daerah selain Aceh yang inkonstitusional. Hal ini dikarenakan bertentangan dengan prinsip-prinsip konstitusi UUD 1945 tentang negara kesatuan. Perlu dipahami bahwa adanya kesatuan dalam bernegara disini dimaksudkan bagi segenap rakyat dan bangsa Indonesia untuk bersatu padu dalam wadah Negara Kesatuan Republik Indonesia, meskipun dalam kenyataannya terdapat keanekaragaman yang berbeda-beda satu dengan yang lain

14 Ibid, hlm. 95.

15 Syahrizal Abbas, "Pelaksanaan syariat Islam di aceh dalam kerangka hukum nasional". Dalam Syahrizal dkk. Dimensi Pemikiran Hukum dalam implementasi syariat Islam di aceh (Banda Aceh: Dinas Syariat Islam Provinsi Nangroe Aceh Darussalam,2007), hlm. 9.

16 Rusdi Sufi dan Agus Budi Wibowo, Budaya Masyarakat Aceh, Bagian Kedua (Banda Aceh: Badan Perpustakaan Provinsi Nanggroe Aceh Darussalam, Jurnal Hukum, Vol. 13 Nomor 2 Penerapan Syariat Islam Aceh dalam Lintas Sejarah), hlm. 3.

17 Hal ini sesuai dengan apa yang terdapat dalam catatan Marco Polo yang melewati Peurlak (Aceh Timur saat ini) dan menggambarkan bahwa kotatersebut (Peurlak) adalah kota muslim pada tahun 1292 dan kerajaan Islam pertama di Indonesia didirikan di Aceh, hal ini dibuktikan dengan penemuan batu nisan Raja Samudra Sultan Malik as-Salih yang tercatat pada tahun 1927. Menurut Ricklefs penemuan ini menunjukkan bahwa kerajaan Islam pertama di Indonesia berada di Aceh. Lihat selengkapnya Arskal Salim, "Shari'a From Below' In Aceh (1930s-1960s): Islamic Identity and the Right to SelfDetermination with Comparative (The Moro Islamic Liberation”, Indonesia and the Malay World, Vol. 32, No. 92, March 2004 Front (Milf)), hlm. 83. 
tetapi tetap menjamin keragaman tersebut sesuai dengan latar belakang sejarah kebangsaan Indonesia yang majemuk. ${ }^{18}$ Oleh karena itu, kemungkinan ketidakseragaman dalam penyelenggaraan pemerintahan daerah itu hal yang konstitusional sepanjang diatur dalam undang-undang yang harus secara tegas mengatur batas-batas apa yang tidak boleh dilanggar, karena bentuk Negara Kesatuan Republik Indonesia bersifat multlak dan tidak dapat ditawar-tawar. Sedangkan berkaitan dengan urusan agama yang seharusnya termasuk kewenangan absolut Pemerintah Pusat dan tidak dapat dibagi oleh pemerintah daerah.

\section{B. Hubungan Pemerintah Pusat dengan Pemerintah Daerah dalam Pengawasan Perda}

Hubungan Pemerintah Pusat dengan Pemerintah Daerah terkait dengan pengawasan Perda dalam rangka memperkuat negara kesatuan yang menganut sistem desentralisasi. Pengawasan dalam tulisan ini tidak dimaksudkan untuk mempersempit atau mengurangi kemandirian daerah dalam menyelenggarakan urusan rumah tangganya, tetapi pengawasan disini menghindari kewenangan pemerintah daerah yang melampaui batas dan dianggap 'berlebihan' yang nantinya akan berpeluang untuk di dominasi kepentingan politik. Sebagaimana dikemukakan oleh Bagir Manan bahwa tidak ada otonomi tanpa pengawasan dan otonomi bukanlah kemerdekaan. ${ }^{19}$ Hal ini berarti pengawasan merupakan simbol negara kesatuan yang hendak mewujudkan keseimbangan antara kecenderungan desentralisasi dan sentralisasi yang dapat diterapkan secara berlebihan. Pemberlakuan perda syariah dibeberapa daerah selain Aceh memang menjadi kewenangan absolut Pemerintah Pusat sebagaimana di atur dalam undang-undang Pemerintahan Daerah.

Meskipun demikian, masih membuka kemungkinan peluang bagi hadirnya perda bermuatan syariat Islam. Hal ini dikarenakan sebagai berikut. Pertama, hubungan antara Pemerintah Pusat dengan Pemerintah Daerah berada pada posisi yang rawan akibat diberlakukannya desentralisasi politik yang mengakibatkan pemerintah daerah mempunyai kewenangan luas untuk mengembangkan kebijakan daerahnya sehingga implikasinya secara terang-terangan dapat menentang kebijakan politik dan hukum dari pusat. Kedua, masih terbuka peluang kewenangan pemerintah pusat untuk mengawasi Perda yang telah diberlakukan melalui mekanisme pengawasan represif, sebagaimana diatur dalam Pasal 251 ayat (2) Undang-undang Pemerintahan Daerah yang diperbarui dengan UU No.23/2014. Pasal tersebut memberikan kekuasaan penuh kepada Gubernur sebagai wakil pemerintah pusat dan Menteri Dalam Negeri untuk menilai, menguji dan membatalkan tekait perda yang dinilai bertentangan dengan peraturan perundang-undangan yang lebih tinggi, kepentingan umum dan atau kesusilaan yang tentunya melalui pertimbangan dan mekanisme politik. ${ }^{20} \mathrm{Hal}$ tersebut

18 Jimly Asshiddiqie, Pokok-pokok Hukum Tata Negara Indonesia Pasca Reformasi, (Jakarta: PT. Bhuana Ilmu Populer, 2007), hlm 288-289

19 Bagir Manan, supra note $2 \mathrm{hlm} .39$.

20 Dalam konsep hukum, pengawasan represif tersebut dikenal dengan pengujian terhadap peraturan perundang-undangan yang berlaku dan mengikat umum. Terdapat 3 kategori besar pengujian peraturan perundang-undangan, yaitu (1) pengujian oleh badan peradilan (judicial review); (2) 
tentu berimplikasi pada pemberlakuan Perda Syariah yang sangat dikuasai oleh kepentingan politik Pemerintah Pusat.

Apabila pemerintah pusat mendukung Perda syariah, tentu tidak dibatalkan dan dianggap konstitusional, meskipun perda tersebut dinilai diskriminatif oleh sebagian kelompok masyarakat. Apabila tidak sesuai dengan kepentingan politik pemerintah, maka dengan mudah Perda Syariah itu dibatalkan. Tentunya, kewenangan ini berpotensi sering disalahgunakan pemerintah dalam pengawasan Perda, sehingga kemungkinan besar putusan menilai, menguji dan membatalkan Perda semata-mata hanya demi kepentingan politik belaka. Oleh karena itu, apabila Perda syariah tetap dibentuk di daerah selain Aceh, maka sama saja itu merupakan upaya pemerintah untuk mempolitisasi agama. Agama dijadikan sebagai alat untuk kepentingan politik di tingkat elite. Hal yang demikian, tentunya membenarkan bahwa supremasi hukum ditundukkan dibawah supremasi politik.

Dengan demikian, pengawasan produk daerah sangat diperlukan untuk mengendalikan dan mengimbangi (check and balance) terhadap kecenderungan kekuasaan yang terpusat dan ditujukan bagi pejabat pemerintahan yang sewenangwenang. Sebagaimana dikeluarkannya putusan MK Nomor 56/PUU-XIV/2016 terkait perda kabupaten/kota yang tidak lagi dapat dibatalkan oleh gubernur dan menteri tetapi dialihkan kewenangannya kepada Mahkamah Agung (MA), ${ }^{21}$ maka ini berarti menjamin tegaknya prinsip supremasi hukum dalam negara kesatuan, karena kewenangan untuk menguji sebaiknya diberikan hanya kepada pengadilan, yaitu melalui mekanisme judicial review. ${ }^{22}$ Hal ini menunjukkan bahwa perda sebagai produk politik tidak boleh dinilai dan diuji oleh lembaga politik dan Pemerintah perlu membatasi kewenangannya hanya pada pengawasan preventif terhadap rancangan perda yang belum berlaku mengikat secara umum. Mekanisme pengujian peraturan daerah yang diberikan kepada Mahkamah Agung, berarti mutlak peraturan daerah dilihat sebagai salah satu bentuk peraturan perundang-undangan yang berada di bawah undang-undang. ${ }^{23}$

Pengujian oleh badan yang sifatnya politik (political review); dan (3) Pengujian oleh pejabat atau badan administratif negara (administrative review). Lihat Ni'matul Huda, Hukum Pemerintahan Daerah, (Bandung: Nusa Media, 2012), hlm. 79.

2l Mahkamah Konstitusi (MK) hanya mengabulkan pengujian Pasal 251 ayat (2), (3), (4), (8) UU No. 23 Tahun 2014 tentang Pemerintahan Daerah yang diajukan Asosiasi Pemerintah Kabupaten Seluruh Indonesia (APKASI) bersama 45 Pemkab. Mahkamah menyatakan aturan mekanisme pembatalan peraturan daerah (perda) kabupaten/kota oleh gubernur dan mendagri inkonstitusional alias bertentangan dengan UUD 1945. Sebagaimana dilansir oleh Agus Sahbani, Catat!! Kini Pembatalan Perda Kabupaten/Kota Wewenang MA, http://www.hukumonline.com/berita/baca/lt58e5f4f15b574/catatkini-pembatalan-perda-kabupaten-kota-wewenang-ma, diakses hari kamis, 06 April 2017.

22 Jimly Asshiddiqie, Perihal Undang-undang, (Jakarta: RajaGrafindo Persada, 2010), hlm. 76.

23 Pasal 7 ayat (1) UU No.12/201l tentang pembentukan peraturan perundang-undangan yang menyatakan bahwa: Jenis dan hierarki Peraturan Perundang-undangan terdiri atas: a. UndangUndang Dasar Negara Republik Indonesia Tahun 1945; b. Ketetapan Majelis Permusyawaratan Rakyat; c. Undang-Undang/Peraturan Pemerintah Pengganti Undang-Undang; d. Peraturan Pemerintah; e. Peraturan Presiden; f. Peraturan Daerah Provinsi; dan g. Peraturan Daerah Kabupaten/Kota. 


\section{Hubungan Antara Pemerintahan Daerah dan Warga Negara}

Hubungan antara Pemerintahan Daerah dan warga negara melalui mekanisme asas legalitas yang berorientasi pada prinsip persamaan hak di hadapan hukum dan pemerintahan (equality before the law principle). Hal ini berarti setiap warga negara harus diperlakukan sesuai dengan nilai keadilan yang menjadi kewajiban pemerintah untuk mewujudkannya dalam praktik, sebagaimana dalam konsep negara hukum modern yang berorientasi pada negara kesejahteraan (welfare state). Pembentukan Perda yang berfungsi sebagai penjaga moralitas terhadap problem kesusilaan yang terjadi di masyararakat merupakan asumsi dan pandangan umum tentang rendahnya pemahaman masyarakat dalam menelaah permasalahan sosial dan menurunnya angka moralitas di masyarakat.

Ketika Peraturan Daerah Nomor 8 Tahun 2005 tentang Pelarangan Pelacuran di kota Tangerang, beberapa organisasi dan aktivis mengkritisi Perda tersebut yang dinilai mendiskriminasikan kelompok perempuan sebagai korban kekerasan atas nama agama. Hal ini terbukti ketika ada seorang ibu yang bekerja di sebuah rumah makan dan baru selesai bekerja pada malam hari. Ibu ini ditangkap oleh petugas meskipun ia telah menyatakan bahwa ia sudah bersuami. Kasus-kasus penangkapan lain juga menimpa perempuan-perempuan yang dengan alasan apapun sedang berada diluar rumah pada malam hari. Akibatnya warga perempuan di kota Tangerang merasa resah dan dibatasi haknya untuk bekerja dan berada di luar rumah. ${ }^{24}$ Dengan demikian, keberadaan perda syariah untuk memperbaiki moral bangsa masih perlu diperdebatkan lagi dan dikaji ulang mengenai kemaslahatannya sehingga tidak menyebabkan diskriminasi bagi sebagian anggota masyarakat. Apabila dikaitkan dengan tujuan dibentuknya Perda maka yang menjadi prioritas bagi pemerintah daerah adalah keadilan yang proporsional terhadap warganya, artinya mereka yang tidak mendapat perlindungan dari pemberlakuan aturan-aturan hukum tersebut juga harus menjadi pertimbangan supaya hak-hak sekelompok warga tersebut dihargai dan tidak boleh membuat yang bersangkutan menjadi parasit demi terwujudnya pembangunan daerah yang berkemajuan. ${ }^{25}$

Dalam negara yang menerapkan hukum modern seperti Indonesia dengan konsep welfare state, pemerintah dibebani kewajiban untuk menyelenggarakan kepentingan

${ }^{24}$ Johanna Poerba, Razia Jilbab, Tes Keperawanan dan Perda Diskriminatif: Kekonyolan Yang Tak Bisa Dibiarkan dalam https:/www.jurnalperempuan.org/blog-mudal/razia-jilbab-tes-keperawanan-dan-perdadiskriminatif-kekonyolan-yang-tak-bisa-dibiarkan, diakses 23-2-2015.

25 John Rawls tentang utilitarianisme hukum mengemukakan bahwa hukum sebagai salah satu unsur yang mengatur susunan dasar masyarakat harus berdasarkan dua prinsip, yaitu: Pertama, menetapkan kebebasan yang sama bagi tiap orang untuk mendapat akses pada kekayaan, pendapatan, makanan, perlindungan, kewibawaan, kekuasaan, harga diri, hak-hak dan kebebasan. Kedua, prinsip perbedaan dan prinsip persamaan atas kesempatan. Prinsip perbedaan (the difference principle) adalah perbedaan sosial dan ekonomi harus diatur agar memberikan manfaat yang paling besar bagi mereka yang paling kurang beruntung, Sedang prinsip persamaan atas kesempatan (the principle of fair equality of opportunity) adalah yang menunjuk kesempatan yang sama bagi semua orang (termasuk mereka yang paling kurang beruntung) untuk mencapai prospek kesejahteraan, pendapatan, dan otoritas. Lihat selengkapnya dalam teori hukum. Lihat selengkapanya dalam Bernard L. Tanya, dkk, Teori Hukum Strategi Tertib Manusia Lintas Ruang dan Generasi, (Yogyakarta: Genta Publishing, 2013), hlm. 86-87. 
umum termasuk terlibat dalam bidang sosial, ekonomi dan kultural masyarakat yang semula merupakan urusan individu. ${ }^{26}$ Keaktifan pemerintah dalam mengatur dan melayani masyarakat harus berdasarkan aturan hukum yang ada. Aturan hukum djalankan sesuai prosedur peraturan perundang-undangan yang berlaku (asas legalitas), namun secara materiil (isi) hukum tersebut mencerminkan perlindungan hak warga negara tanpa terkecuali yang bersumber dari prinsip-prinsip Pancasila. Oleh karena itu, dalam mengukur indikator-indikator mengenai keberhasilan pembangunan suatu daerah, tidak hanya didasarkan pada pertimbangan moral tetapi suatu keadilan yang proporsional. ${ }^{27}$

Dengan menggunakan asumsi dasar bahwa hukum sebagai produk politik, bahwa kehendak para pemimpin daerah, yakni mereka yang memegang posisi dominan di lingkungan Pemerintahan Daerah tentunya akan sangat menentukan dalam pembentukan Perda. Apabila para pemimpin daerah memiliki pandangan agama yang progresif demi kesejahteraan rakyat, maka produk hukum yang dihasilkan adalah berkarakter responsif, yakni menempatkan peran agama sebagai kekuatan sosial untuk lebih memperbaiki kehidupan masyarakat. Namun sebaliknya, apabila pemimpin daerahnya itu memiliki pandangan agama yang kaku dan lebih berorientasi pada ibadah dalam arti sempit, maka ketika menyelesaikan suatu persoalan moral di masyarakat adalah dengan menggunakan kaidah-kaidah yang bernuansa syariah untuk diformalisasikan melalui Perda Syariah. Hal ini dipergunakan untuk mencapai tujuan, yakni menciptakan masyarakat yang berkepastian hukum, tertib dan adil meskipun peraturan tersebut sama sama sekali tak ada yang bersinggungan dengan kondisi riil masyarakat.

Berapangkal dari uraian diatas, maka dalam konsep negara welfare state seorang Pemimpin Daerah memelukan strategi yang tidak hanya sekedar menjalankan kekuasaannya secara otoritarian dengan berorientasi pada kepetingan sekelompok elit penguasa yang dominan melalui pembentukan dan formalisasi perda syariah, sebagaimana dikemukakan oleh Nonet dan Selznik, apabila hukum terikat pada status quo, maka pihak yang berkuasa dan dominan mempunyai kewenangan yang sah menuntut warga negara agar mematuhi kekuasaan yang bertahta. ${ }^{28}$ Oleh karena itu, pemahaman posisi dan peran agama tidak boleh direduksi dalam wilayah formalisasi kebijakan tetapi hendaknya pemerintah dengan dorongan nilai etis agama mampu menjamin hak-hak warganya dalam hukum dan pemerintahan melalui pengakuan dan

26 Ridwan HR, Hukum Administrasi Negara Edisi Revisi, (Jakarta: PT. Raja Grafindo Persada, 2014), hlm. 133.

27 Indikator terakhir keberhasilan pembangunan suatu bangsa adalah ukuran keadilan sosial dan kesinambungan. Masuknya faktor keadilan sosial dalam tolok ukur pembangunan bukan hanya berdasarkan pertimbangan moral belaka, tetapi digunakan untuk pelestarian pembangunan itu sendiri. Hal ini karena jika terjadi kesenjangan yang besar antara orang-orang kaya dan miskin, maka masyarakat yang bersangkutan akan rawan secara politis. Bila terjadi pergolakan sosial yang ditimbulkan dari kesenjangan ini, maka hasil pembangunan yang sudah dilakukan tentu akan sulit dicapai.Lihat selengapnya dalam Irawan dan Suparmoko, Ekonomika Pembangunan, (Yogyakarta: BPFE, 1992), hlm. 25.

28 Moh Mahfud MD, Politik Hukum di Indonesia, (Jakarta: PT. Raja Grafindo Persada, 2012), hlm. 27. 
jaminan pelibatan partisipasinya dalam merumuskan kebijakan daerah mulai dari prosedur perencanaan, monitoring, dan evaluasi terikat pada kuatnya masyarakat.

\section{KESIMPULAN}

Secara formil, perda Syariah sama pembentukannya dengan perda-perda biasa. Oleh karena itu apabila dikaitkan dengan hierarki norma dalam Pasal 7 ayat (1) Undangundang No.12/2011 tentang pembentukan peraturan perundang-undangan maka jelas nyatalah bahwa Perda yang bermuatan syariah yang kedudukannya berada di bawah undang-undang dan jenisnya adalah produk hukum yang dibuat oleh legislasi dan pemerintah di tingkat lokal dan berlaku asas hukum lex superior derogate legi inferiori. Berbeda dengan Aceh yang telah diberi hak otonomi khusus melalui UU Nomor 11 Tahun 2006 tentang Pemerintahan Aceh., maka berlaku asas hukum, lex spesialis derogate lex generalis yaitu aturan hukum khusus yang mengecualikan aceh dari Undang-undang Pemerintahan Daerah.

Secara materiil pembentukan Perda Syariah dalam arti sempit ritual di daerah selain Aceh berpotensi untuk dibatalkan oleh Mahkamah Agung setelah Pemerintah tidak lagi dapat membatalkan Perda karena dianggap cacat yuridis dan substansi yang jelas bertentangan dengan prinsip NKRI. Namun, untuk menyiasati supaya nilai-nilai Islam tetap masuk dalam Perda, maka DPRD dan pemerintah daerah boleh memperjuangkan nilai-nilai Islam ke dalam bentuk Perda tanpa menformalkan syariah dan substansi materinya tidak sempit ritual tetapi lebih kepada jaminan perlindungan terhadap golongan marginal, diskriminatif dan minoritas, sehingga nantinya tetap menjiwai Perda itu sendiri sebagai sumber materiil yang membawa kepentingan maslahah.

\section{DAFTAR PUSTAKA}

Asshiddiqie Jimly, 2010, Perihal Undang-undang, (Jakarta: RajaGrafindo Persada).

Asshiddiqie Jimly, 2014, Pengantar Ilmu Hukum Tata Negara, Cet.6 (Jakarta: Raja Grafindo Persada).

Asshiddiqie, Jimly, 2007, Pokok-pokok Hukum Tata Negara Indonesia Pasca Reformasi, (Jakarta: PT. Bhuana Ilmu Populer).

Dalmeri, 2012, Prospek Demokrasi: Dilema antara Penerapan Syariat Islam dan Penegakan Hak Asasi Manusia Indonesi, (Jakarta: SALAM, Jurnal Studi Masyarakat Islam).

Evanty Nukila, dkk, 2014, Paham Peraturan Daerah (PERDA)Berperspektif HAM (Hak Asasi Manusia), (Jakarta: PT. Raja Grafindo Persada).

HR Ridwan, 2014, Hukum Administrasi Negara Edisi Revisi, (Jakarta: PT. Raja Grafindo Persada).

Huda Ni'matul, 2012, Hukum Pemerintahan Daerah, (Bandung: Nusa Media) 
Indrati Maria Farida, 2007, Ilmu Perundang-undangan 1, Jenis, Fungsi, Materi Muatan (Yogyakarta: Kanisius).

Indrayana Denny, 2010, Kompleksitas peraturan daerah bernuansa syari'at prespektif hukum tata negara, (tidak ada kota: Jurnal Yustisia Edisi8l September-Desember).

Irawan dan Suparmoko, 1992, Ekonomika Pembangunan, (Yogyakarta: BPFE).

Jordan Roy, 2016, Mendagri: Tidak Ada Penghapusan Perda Syariat Islam https://news.detik.com/berita/3234905/mendagri-tidak-ada-penghapusan-perdasyariat-Islam, diakses hari kamis 16 Juni 2016, Pukul 13.57 WIB.

Latif Yudi, 2013, Negara Paripurna historisitas, rasionalitas, dan aktualitas Pancasila, (Jakarta: PT Gramedia).

MD Mahfud Moh, 2010, Membangun Politik Hukum, Menegakkan Konstitusi, (Jakarta: PT.Rajagrafindo Persada).

MD Mahfud Moh, 2012, Politik Hukum di Indonesia (Jakarta; PT. Raja Grafindo Persada).

Manan Bagir, 2002, Menyongsong Fajar Otonomi Daerah, (Yogyakarta: Pusat Studi Hukum (PSH) Fakultas Hukum UII).

Muntoha, 2010, Otonomi Daerah dan Perkembangan Peraturan Daerah Bernuansa Syariah, (Yogyakarta: Safiria Insania Press).

Poerba Johanna,2015, Razia Jilbab, Tes Keperawanan dan Perda Diskriminatif: Kekonyolan Yang Tak Bisa Dibiarkan dalam https:/www.jurnalperempuan.org/blog-mudal/raziajilbab-tes-keperawanan-dan-perda-diskriminatif-kekonyolan-yang-tak-bisadibiarkan, Edisi 23-02-2015.

Republik Indonesia, Undang-Undang Dasar 1945 Perubahan .

Republik Indonesia, Undang-undang No.22/1999 jo UU. No. 32/2004 jo UU No.23/2014 Tentang Pemerintahan Daerah.

Republik Indonesia, Undang-Undang No. 12/2011 Tentang Pembentukan Peraturan Perundang-undangan.

Republik Indonesia, Putusan Mahkamah Konstitusi Nomor 56/PUU-XIV/2016.

Republik Indonesia, Peraturan Daerah Kabupaten Tangerang No.8 Tahun 2005 tentang Pelarangan Pelacuran.

Republik Indonesia, Peraturan Daerah Kota Malang No 8 Tahun 2005 Tentang Larangan Tempat Pelacuran dan Perbuatan Cabul.

Sahbani Agus,2017, Catat!!! Kini Pembatalan Perda Kabupaten/Kota Wewenang MA, http://www.hukumonline.com/berita/baca/lt58e5f4fl5b574/catat-kinipembatalan-perda-kabupaten-kota-wewenang-ma, edisi kamis, 06 April 2017.

Salim Arskal, “Shari'a From Below' In Aceh (1930s-1960s): Islamic Identity And The Right To SelfDetermination With Comparative ( The Moro Islamic Liberation", Indonesia And The Malay World, Vol. 32, No. 92, March 2004 Front (Milf)).

Sufi Rusdi dan Wibowo Budi Agus, Budaya Masyarakat Aceh, Bagian Kedua (Banda Aceh: Badan Perpustakaan Provinsi Nanggroe Aceh Darussalam, Jurnal Hukum, Vol. 13 Nomor 2 Penerapan Syariat Islam Aceh dalam Lintas Sejarah). 
62 | Pembentukan Peraturan Daerah Syari'ah dalam Perspektif Hukum Tata Negara Pascareformasi

Syahrizal dkk, 2007, Dimensi Pemikiran Hukum dalam implementasi syariat Islam di aceh (Banda Aceh: Dinas Syariat Islam Provinsi Nangroe Aceh Darussalam).

Tanya Bernard L, dkk, 2013, Teori Hukum Strategi Tertib Manusia Lintas Ruang dan Generasi, (Yogyakarta: Genta Publishing).

Warijo, 2015, Politik Belah Bambu Jokowi: Dari Mafia Politik Sampai Islamfobia, (Medan: Puspantara). 